DOI: https://doi.org/10.24113/ijellh.v8i1.10414

\title{
A Story of Scattered Hearts: Kiran Desai's The Inheritance of Loss
}

Dr. Varsha Vaidya

Professor

Taywade College

Koradi, India

drvarshavaidy1972@gmail.com

Mr. Siddharth Patil

Research Scholar

Taywade College Koradi

Asst. Prof. RLMM Sawargaon,

India

\section{Abstract}

Human beings are so fragile and impatient that they are easily subjected on emotional basis. It is in human nature that they empathise everything that emotionally attach with them. Emotion plays a vital role in the entire world of human relationship. It is not inept to note here that our thoughts are often forms the core of our actions. It reflects the framework of our psychology greatly. There are instances in the world of living where one work affects because of the mood 
DOI: https://doi.org/10.24113/ijellh.v8i1.10414

of a person. Deliberately, the writers across the world develop and circle their thoughts around emotional balance of human beings in various points. They successfully stress the effect of a particular crisis and it's outcomes on human mind. The present research paper deals with the effects of such crisis on the lives of human being who are deeply engulfed in their normal life. The study is a sincere endeavour to bring to the fore a serious effect of Nepali-a politically motivated-uprising on the common man living peacefully, amicably in harmony with nature.

Keywords: Globalization, Other, Loss, Humiliation, Discrimination Etc.

Introduction

Kiran Desai with her 'strange happening in the guava orchard' was introduced to the literary world by Sir Salman Rashdie- a literary stalwart. A daughter of the renowned novelist and three times the man booker prize shortlisted novelist Anita Desai, Kiran developed the literary taste and imbibe it in a homely atmosphere from her mother. Her mother's advice of opting for Creative Writing Program proved beneficial to her. She accumulated her literary assets and using them in her first work brought her the Bretty Trask Prize- an award given to the new writers of commonwealth nation under the age of thirty five for their maiden novel by the society of authors since 1984. Kiran Desai bagged the prize for her first novel published in 1998 Hullabaloo in the Guava Orchard in the same year. The novelist of a critically acclaimed maiden novel, she took a seven year break. She appeared on the literary zone and brightly lightening it with her second novel The Inheritance of Lossin 2006 receiving the most coveted the Man Booker Prize in the same year. She is the youngest novelist to win such an award which lured her novelist mother almost three times.

Kiran Desai is an Indian born author lives in US with her mother Anita Desai. She lived in India till the age of fourteen and left for England with her mother. She spent nice time living 
DOI: https://doi.org/10.24113/ijellh.v8i1.10414

in various parts of India and collected her experiences to disclose them through her novel. She wanted to study science but literary taste allured her developing her senses for expressions. It is the mother who motivated her daughter to opt for the creative writing course. The literary inheritance of her mother and father continued to attract its successor. The book shelves at home interested Kiran and she read the literary books to enrich her taste only out of curiosity. She often visits her hometown Delhi and appears on literary festivals intermittently. Her the Man Booker Prize winner second novel narrates the lives of common people spending their time in serenity. The Inheritance of Loss with its very title focusses on the loss of human and universal values of liberty, equality and fraternity. The globalisation plays a vital role in developing a sense of 'the world is my home' concept, liberating any person to live anywhere. The globalization has brought all the world at a click. The people make home to any country for their opportunistic ideology. They migrate from one place to another place for the sake of money, career, or to change their living. In her novel 'The

Inheritance of Loss', set in 1980's Kiran Desai presented the lives of such people who shifted to new places making it as their home, living peacefully.

The Retired Judge of colonial era JemubhaiPopatlal Patel purchases a solitary house named Cho Oyu in the lap of Kalimpong, a beautiful town surrounded by the Mount

Kanchenjunga. He lives with his pet bitch 'the Mutt', 'the Cook', and his granddaughter Sai-a convent educated sixteen year old girl- who is orphan. The Judge loves silent and serene life avoiding all relations far and near. His colonial life is full of stress and emotional conflict that he abandons everyone outside his home, showering all his love on his cute bitch the 'Mutt'. He does not try to learn the Nepalese language of the locals. His education in England experiencing and exploring the bitter racism in the form of embarrassment and develops hate for his Indian culture and people, becomes stranger to himself. His all-rounder servant 'the cook' follows his 
DOI: https://doi.org/10.24113/ijellh.v8i1.10414

order without a word. The novelist does not mention his name throughout the entire novel except once. The cook has no identity in particular as he performs all the duties. He is not a native of Kalimpong but shifts with his master only to support his son Biju by sending him to US to follow 'American Dream' that would enable him to buy a T.V., a sopha, and other luxuries only enjoyed by the rich. Sai lives with these two old people securing her youthful exuberance which helps her to keep up with the latest technology and knowledge. She likes to be independent like her parents. She dreams and aspires to be a scientist like her father. All the three living in Cho Oyu secretly mingle with their past, present, and future by consoling their hearts.

The anglophile Bengali sisters Lola-a widow and Noni-a spinster live in their luxurious home named Mon Ami enjoying English lifestyle entirely. Lola's husband Joydeep decides to buy a property at Kalimpong only to spend peaceful retirement life in the bosom of nature. After owning Mon Ami, he dies of a heart attack living his wife alone. Lola calls her spinster sister Noni to stay with her. Her daughter Pixie is at BBC in England whom they often see on television and appreciates her. They live on the pension of Joydeep to which

Noni adds by tutoring Sai. The sisters don't mingle with locals rather they hires a maid, a gardener, a watchman, and a sweeper. They don't have faith on the locals despite exploiting their duties. They suspect their loyalty on the basis of the rich and the poor, the natives and the foreigners. They are often engaged in a conversation with their servants but don't reveal their secrets to them such as dealing with their personal life. They are high class readers and critiques who often visit to the Gymnkhana Library and spend most of their time in discussing nationalinternational matters. They have nothing to do with the problems of the local Nepalese who are in momentum gathering their people against the 'Others'. They are planning to form agitation rallies too. The native of Switzerland Father Booty-a dairy owner who educates the locals about dairy production and provides dairy products to the locales living illegally without papers in his 
DOI: https://doi.org/10.24113/ijellh.v8i1.10414

solidly constructed house named 'Sukhtara' since long time. He does not overload himself with renew his citizenship. He spends his time with his friend Uncle Potty forming a gay couple. Uncle Potty gets his family fortune in his pocket enjoys his life with drinking and singing on piano. He is not a native of Kalimpong too, considering his ownership on his purchased home to spend composed time with nature.

Speaking about the cook's son Biju, he lives in America; living a life of an illegal immigrant; jumping from one job to another. Biju comes in America after a long struggle for a week to make it big in America to join hands with his father's friend. But he asks Biju in his first meeting to leave for India as soon as possible as there is no life in America. Despite the advice of his father's friend, Biju determines not to bow down and try his luck as a cook in American restaurants. Every now and then, he is thrown out of his job on the basis of his

Indian smell, skin or illegality. He asks his father not to worry about him as he works for America, he is getting healthy day by day which is absolutely opposite. In fact, he eats unhealthy food, lives in kitchen basements surrounded by dirt and mice with no prime amenities. The restaurant owners exploit the illegal workers from all over the world. The harsh reality of the American restaurants appears before Biju's naked eyes. Suffering a lot, Biju is still optimistic that one day he would get his identity by getting Green Card to which he spends almost his income whenever he is promised to get it but in vain. He finds that the Indian caste system follows him here in America too ashis restaurant owner Harrish Harry exploits him on the name of Mahatma Gandhi. Living in poor conditions, he tries to save money for his future and determines to return India with handsome money which would help him to set up his own business.

Gyan is a twenty years old, a graduate student; an unemployed; handsome youth. His family living in dire conditions expects him to get employment as soon as it is possible. 
DOI: https://doi.org/10.24113/ijellh.v8i1.10414

Achieving graduate degree is not enough to get a job as he experiences the regional 'being Nepali' discrimination. He accepts to tutor Sai, the retired judge's granddaughter, to teach math and science. He gets little out of his tutoring Sai and has to complete a long distance from his home to her residence, Cho Oyu. He often ponders over the fact if he gets late, the Judge would cut his salary. Meanwhile Gyan and Sai attract towards each other in their tender age to which Gyan enjoys his visit to Cho Oyu, a luxurious mansion having spacious rooms, a spacious bathroom in which his entire family can comprise. He does not reveal to Sai about his poverty stricken family and his home. Both spend a quality time in wandering through roads, restaurants, library and gardens of Kalimpong. Sai is unknown to poverty stricken people and is polished by English manners still longs for her love whenever Gyan fails to reach at Cho Oyu.

Thus life continues of all the common people living in their own world until the breakdown of GNLF movement. It gradually appears on the scene when everyone is busy in their own web. The GNLF movement is evoked out of the political stunt to highlight the problems of native Nepalese who are being treated as minority in a place where they are in majority. The frustration arising out of their age old problems unemployment, illiteracy, poverty, and lack of primary amenities are on the verge. The youth is involved to gather agitation against the 'others' and to make it a successful bloody movement which would result in getting a separate state for the Nepalese. The band of youth is motivated and enraged by hateful speeches by the local leaders who support them with money and machinery. It is mandatory for each member of a family living in Hillside to appear in the rally organised by the GNLF (Gorkha National Liberation Front) movement.And the story takes a turn after the bitter violence bombing, gunning and lathi-charge in the rally where people losses their lives including policemen too. Stones are pelted, people are gunned down and never seen before situation is raised out of control. The agitation of locals getting infuriated by the police lathicharge, the 
DOI: https://doi.org/10.24113/ijellh.v8i1.10414

movement takes a wrong turn in looting the rich, raping women, and encroaching the land of non-natives by setting small huts on the land of non-natives.

The lives of non-natives begin to disturb by the outrageous activities of the political uprising. The retired judge's house is invaded by a band of notorious youth who get in for guns of the retired judge. They are informed by Gyan, Sai's tutor and lover putting his lady love in danger. The horrified cook first by witnessing the bitter violence at the market and now at his master's home begs mercifully to spare his life only to see his son again. His master, the retired judge is humiliated in front of his granddaughter and his servant. They leaves the place by looting, guns and defecating the toilet. The cook is believed to be suspect in the case of robbery. He also losses his contact with Biju, his son. The dire violence that breaks out makes him believe that he would not live longer to see his son again. Sai gets knowledge about Gyan'sprovidinginformation to the robbers putting her in danger hates him and quarrels with him over the issue to which Gyan beats her with a stick in front of his sister. Sai visiting Gyan comes to know his poverty and hates her choice of Gyanwho is intruder and informer. On the other hand, Gyan out of his agitation, realizing his own poverty and unemployed condition by accidentally witnessing a speech of a local leader in the market rally while buying rice, informs the robbers about the guns in the house Cho Oyu. He feels the difference between Sai's English manners, lifestyle and his own poor-poverty stricken lifestyle. He hates being unemployed and poor. Gyanhurts Sai in hypocrisy. The intruders invade the anglophile sister's house humiliating them. Their courtyard is encroached by the setting up huts of locals to which she complains it to Pradhan by visiting his home. The Pradhan sourly humiliates her by offering a marriage proposal to be his fifth wife. Hurtled

Lola repents over her husband's decision to lead a peaceful life at Kalimpong where they are treated now as 'others'. Father Booty is found living illegally without paper in his detention by 
DOI: https://doi.org/10.24113/ijellh.v8i1.10414

the police, so he is advised forcefully to leave the place immediately as soon as it is possible leaving all his property to the locals and having no meaning. Father Booty leaves the place with heavy heart and is separated by his friend Uncle Potty only to mourn in drinking and singing alone.Biju, the cook's son, living in America, working in Gandhi Café skids and breaks his left leg. He blames the owner who does not provide him doctor on the basis of illegality. Meanwhile he learns from his well-wisher that there is an emergency in Kalimpong, Darjeeling and people are running to and fro to save their lives. He also fails to contact his father so he finally determines to return India with all his savings to see his father despite the advice of Mr Kakkar. However he arrives India, Darjeeling airport and finds no transportation, finally gets a seat in a jeep of GNLF boys who in turn robs him with all his belongings, savings and almost his shoes, shirt-pant, watch except his underpants. Biju, however,maintains to reach at Kalimpong and calls his father from the gate of Cho Oyu. The cook is bitterly beaten by his master almost to death on the cause of losing the 'Mutt'. In fact, the bitch is stolen by the drunken man's wife and father to earn money by selling her to a rich person. The drunken man is caught from the market on the suspicion of robbing guns from Cho Oyu as it is a poor person who bear the brunt of police suspicion.

\section{Conclusion}

In conclusion, all the characters in the novel 'The Inheritance of Loss' are suffered bitterly as they lose their hearts for some or a particular reason in the wake of GNLF movement. They are caught in the whirlpool of destined circumstances only to suffer a loss of dignity, love, care, money, property, peace, human values etc. in no reason. They become the puppets in the hands of destiny and find no solace till the end of the story. Their expectations turn disassociating themselves from their goal of living amicably with the natural surroundings of the Hillside and shattering their dreams only to return with a heavy heart to their miserable state. 
DOI: https://doi.org/10.24113/ijellh.v8i1.10414

The novelist Kiran Desai has succeeded in her attempt to bring the sufferings of such losses to the fore of academic international level. It is her modest effort to give a voice to the bitter experiences of such lives who suffered a lot on the basis of discrimination. The novel is recognized as highlighting the universal truth as the 'otherness' belongs to all. 
DOI: https://doi.org/10.24113/ijellh.v8i1.10414

Reference

Desai Kiran, The Inheritance of Loss, New Delhi: Penguin Books, 2006 